\title{
STOP 4: Internal structure and genesis of the sediments underlying Terrace III of the River Gauja at Dukuḷi farmhouse and Valmiera town
}

Māris Krievāns and Agnis Rečs

University of Latvia

\section{Dukuli Outcrop $\left(25^{\circ} 23^{\prime} 17^{\prime \prime} E\right.$, 57 $\left.27^{\prime} 46^{\prime \prime} N\right)$}

The outcrop is located on the scarp of Terrace III, near the Dukuli farmhouse. It stretches along the right cutbank of the River Gauja, $4.1 \mathrm{~m}$ above the lower mean river water level at this site and $33.4 \mathrm{~m}$ a.s.l. The lithological composition of the exposed sequence exhibits numerous characteristics that point towards the glaciolacustrine origin of the sediments. The thickness of these sediments (Fig. 4.1) reaches up to $4.5 \mathrm{~m}$.
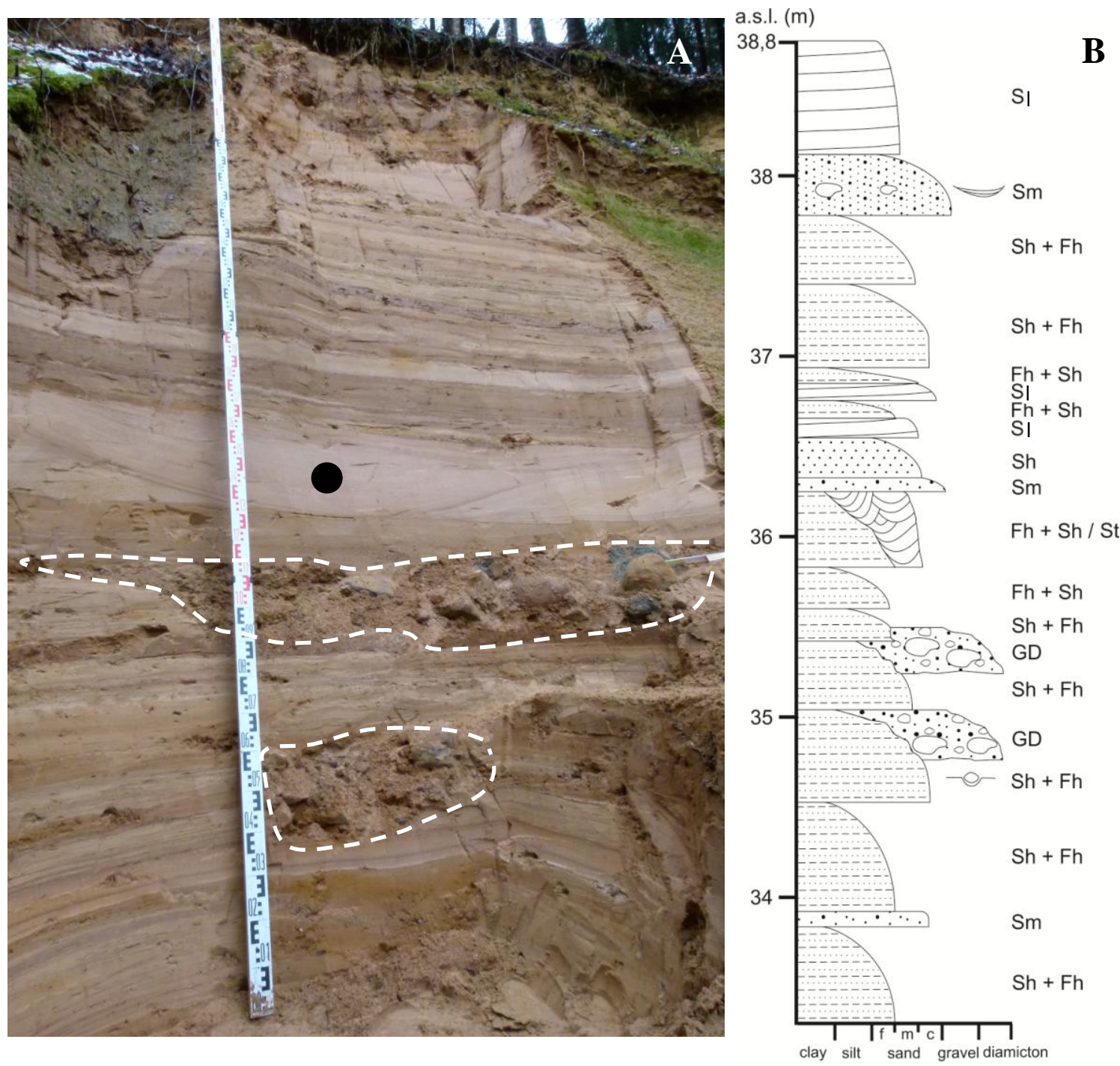

Fig. 4.1. Lithological composition (A) and sedimentary $\log (\mathrm{B})$ of the outcrop on the scarp of Terrace III of the River Gauja, near the Dukuli farmhouse. Legend: GD - diamictic gravel; Sl - low-angle cross-bedded sand; Sm massive sand; Sh - horizontally bedded sand; St - trough cross-bedded sand; Fh - parallel laminated silt. Dashed lines show contours of supraglacial diamicton lenses; black dot indicates location of the OSL sampling site.

The lower part of the sequence consists of fine-grained sand interbedded with silt, with an admixture of clay. In the lower part of the outcrop there are a couple of supraglacial till lenses cased in stratified material (Fig. 4.1). The topmost part of the section consists of silt 
and fine-grained sand with weakly expressed ripple cross-laminae (Fig. 4.1).

The lithological composition, textures and facies analysis of the sediment units provide evidence that they accumulated in a basin, probably in a glaciolacustrine environment, rather than being of alluvial origin, as interpreted in previous studies (Ābolkalns et al. 1960). Still uncertain is the question of the genesis of Terrace III of the River Gauja. In previous studies (Ābolkalns et al. 1960; Āboltinss 1969, 1971), both of the highest terraces of the lower complex (Terrace III and Terrace II) were related to levels of the stage Bgl II and phase Bgl III $_{\mathrm{b}}$ of the Baltic Ice Lake (Grīnbergs 1957; Āboltinš 1971). Next to the Liěci Sanatorium, in Terrace III of the River Gauja, below floodplain alluvium, macroscopic plant remains were found. Accumulation of these plant remains occurred as early as 10,535 \pm 0.25 (Ri-33) and $10,282 \pm 0.25$ (Ri33A) ${ }^{14} \mathrm{C}$ years BP (Stelle et al. 1975a, b). The sediment depositional environment was interpreted as an oxbow lake and floodplain members (Ābolkalns et al. 1960; Āboltiñs 1971). The latest studies of the outcrop, exposing the internal structure of the riser of Terrace III on the right bank of the river north of the Dukuli farmhouse, testify to sediment deposition in a palaeobasin in contact with dead ice. Such an interpretation is also supported by evidence of supraglacial diamicton lenses in the lower part of the outcropping section (Fig. 4.1). Only the upper part of the outcrop (Fig. 4.2) indicates an alluvial or alluviallacustrine sediment accumulation environment, which came about as a result of drainage from a meltwater basin.
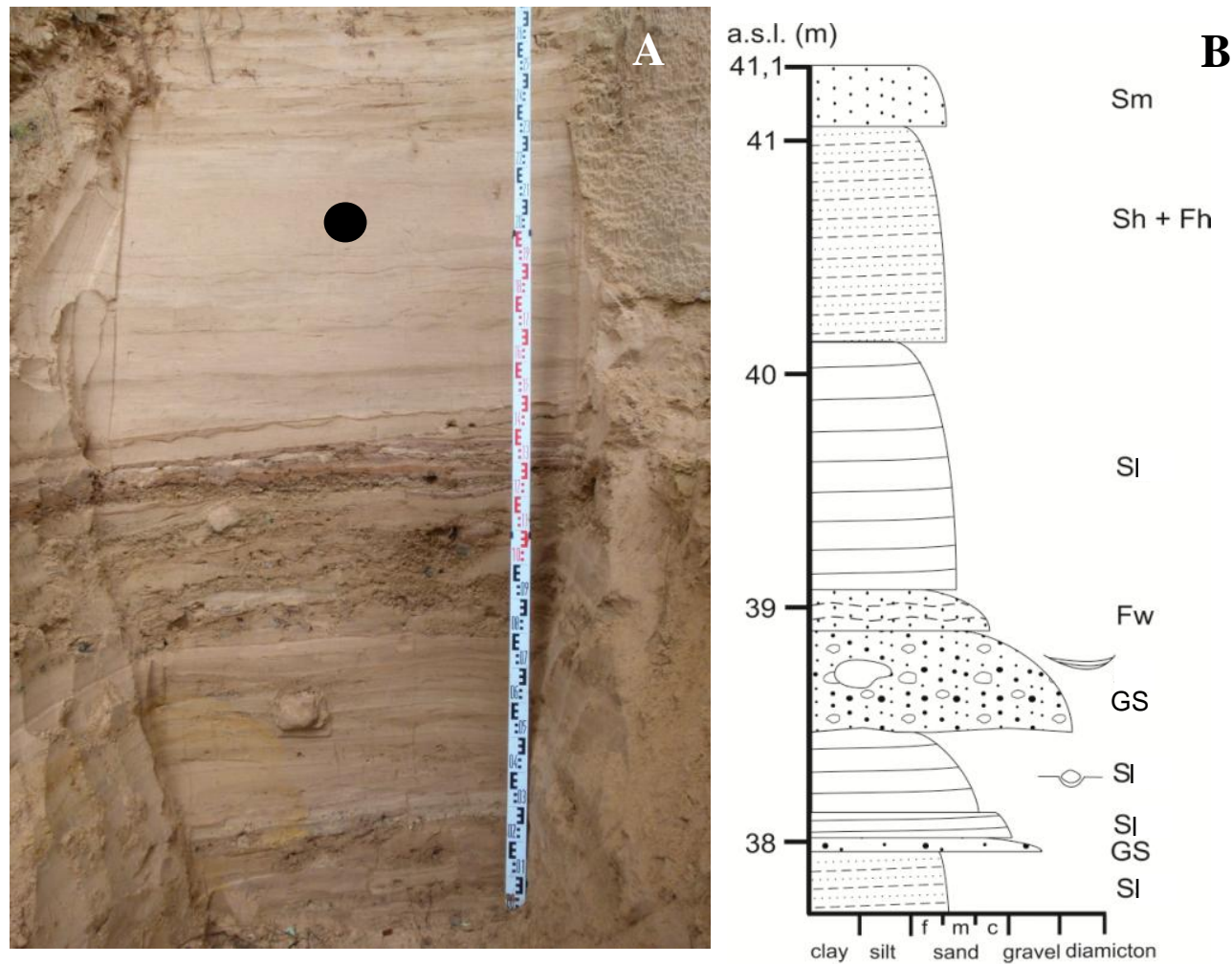

Fig. 4.2. Lithological composition (A) and sedimentary $\log (\mathrm{B})$ of the upper part of the section at the Dukuli farmhouse. Legend: GS - sandy gravel; Sm - massive sand; Sh - horizontally bedded sand; Sl - low-angle crossbedded sand; Fh - parallel laminated silt; Fw - wavy laminated silt. Black dot indicates the position where the OSL dating sample was taken.

After palaeobasin leaking, downcutting and erosion terrace formation started in the River Gauja valley. Therefore, this sedimentary sequence has been distinguished from the formation of Terrace III. According to geological and geomorphological evidence (Āboltinšs 1971), downcutting occurred at this time and the riverbed gradually narrowed. 


\section{Steep Banks Outcrop $\left(25^{\circ} 26^{\prime} 41^{\prime \prime} E, 57^{\circ} 32^{\prime} 45^{\prime \prime} N\right)$}

The outcropping scarps known as the Steep Banks ('Stāvie krasti') constitute one of the best-known geological monuments of Latvia. These scarps open out along the right cutbank of the River Gauja, $1 \mathrm{~km}$ downstream of the embouchure of the River Abuls, and almost $250 \mathrm{~m}$ downstream of the Dalini farmhouse, in the territory of Valmiera town. Due to erosion by the River Gauja in springs the Steep Banks consist of a 280-m-long series of fresh exposures (Fig. 4.2). The height of the scarps varies between $10 \mathrm{~m}$ and $15 \mathrm{~m}$, and the width of some sections can be up to $80 \mathrm{~m}$. Detailed study of the sediments forming the Steep Banks was carried out in the cutbank of the river meander in a $13.3 \mathrm{~m}$ high outcrop (Fig. 4.3), the upper head of which is located $43.1 \mathrm{~m}$ a.s.l. The lowermost part of the outcrop is occasionally covered by talus a few metres (up to $4 \mathrm{~m}$ ) thick. The Steep Banks have been known for long time and are considered as providing one of the most complete records of Terrace III of the River Gauja (Āboltiņš 1969, 1971).
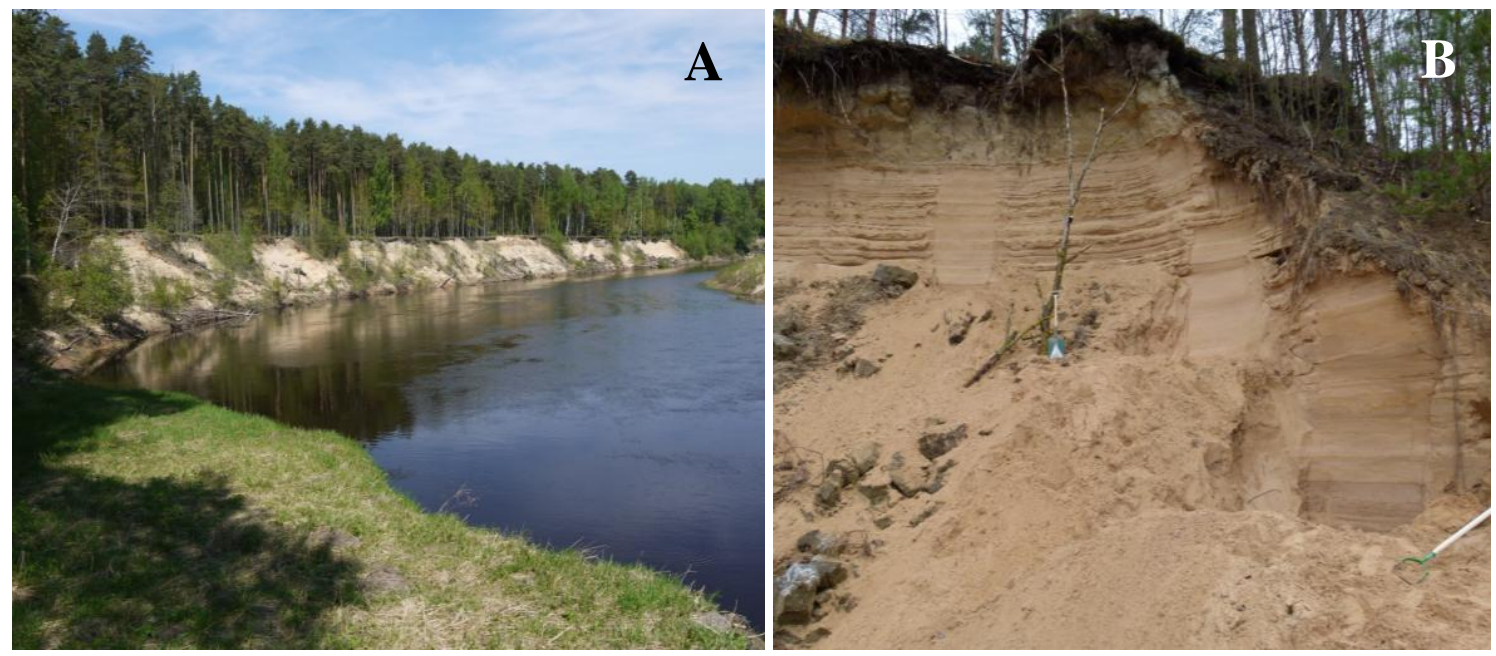

Fig. 4.3. View of the partly outcropping scarps of the Steep Banks (A) and a portion of the outcrop studied in detail (B).

Based on the results of composition, structure and rhythmic changes of the lithofacies, the upper $7.25 \mathrm{~m}$ of the scarp can be divided into 44 sedimentation rhythms. According to their characteristics, these rhythms can be grouped into four facies associations (Fig 4.4).

In the part of the section under consideration the typical sedimentation rhythm starts with partial or thorough washing-away of the upper part of the underlying rhythm. Thus, the lower part of the rhythm is formed by horizontally layered fine-grained clay and silty sand with a silt admixture. The horizontal structures possibly do not indicate slow water flow, but actually provide evidence of relatively rapid flow, which forms in the upper flow regime of a watercourse. In the upper flow regime resistance to flow is small and sediment transport is high. Planar lamination forms when the flow is strong enough that the beds flatten out. The momentum of the transported grains and fluid is high enough that they tend to move horizontally, eroding any irregularities in the bed. In the rhythms the granulometric composition decreases upwards and current ripples appear; at the end of the rhythm the ripples are covered with silt or a silty clay lamina. In the middle part of the section water current climbing ripples turn into sinusoidal ripples, which are capped by silty clay lamina a few millimetres thick. The next rhythm starts with partial washing-away of the previous layer and ripples. According to the lithological composition in the upper $2.05 \mathrm{~m}$ of the outcrop two associations of facies can be distinguished, overlain by a massive sand layer. 
a.s.l. (m)

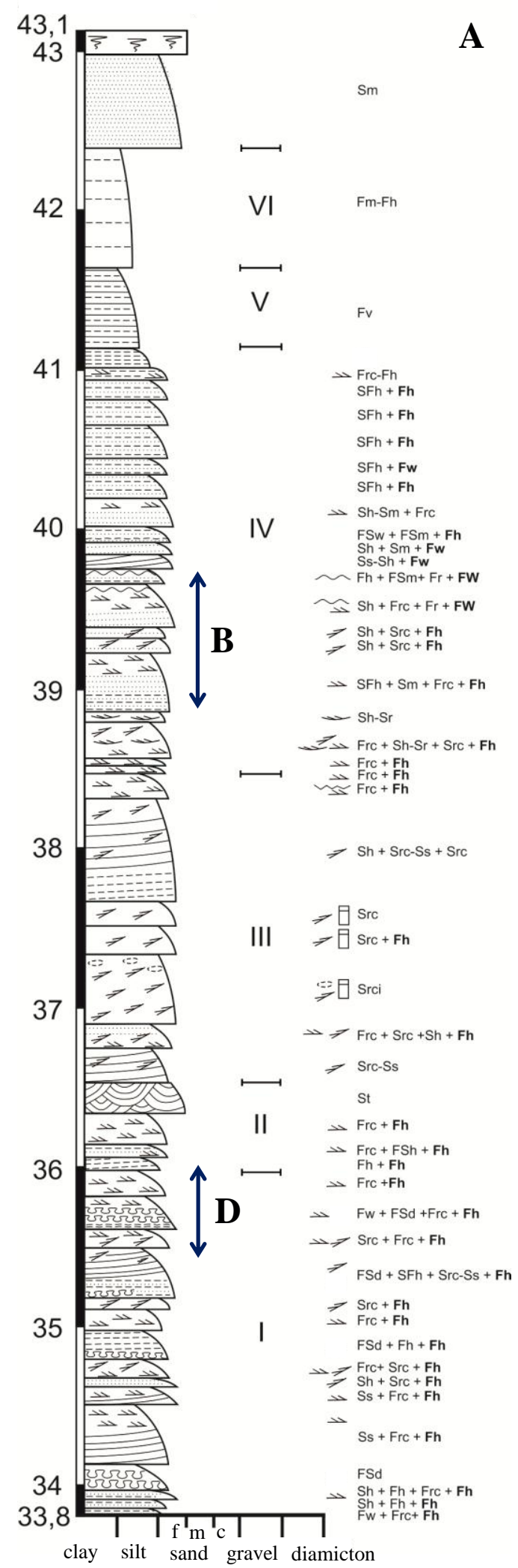

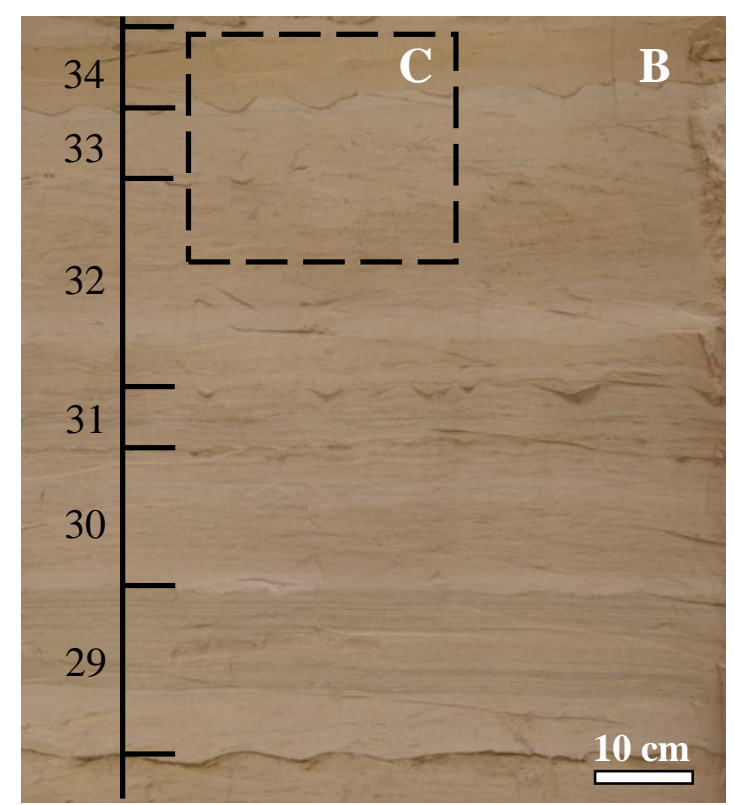
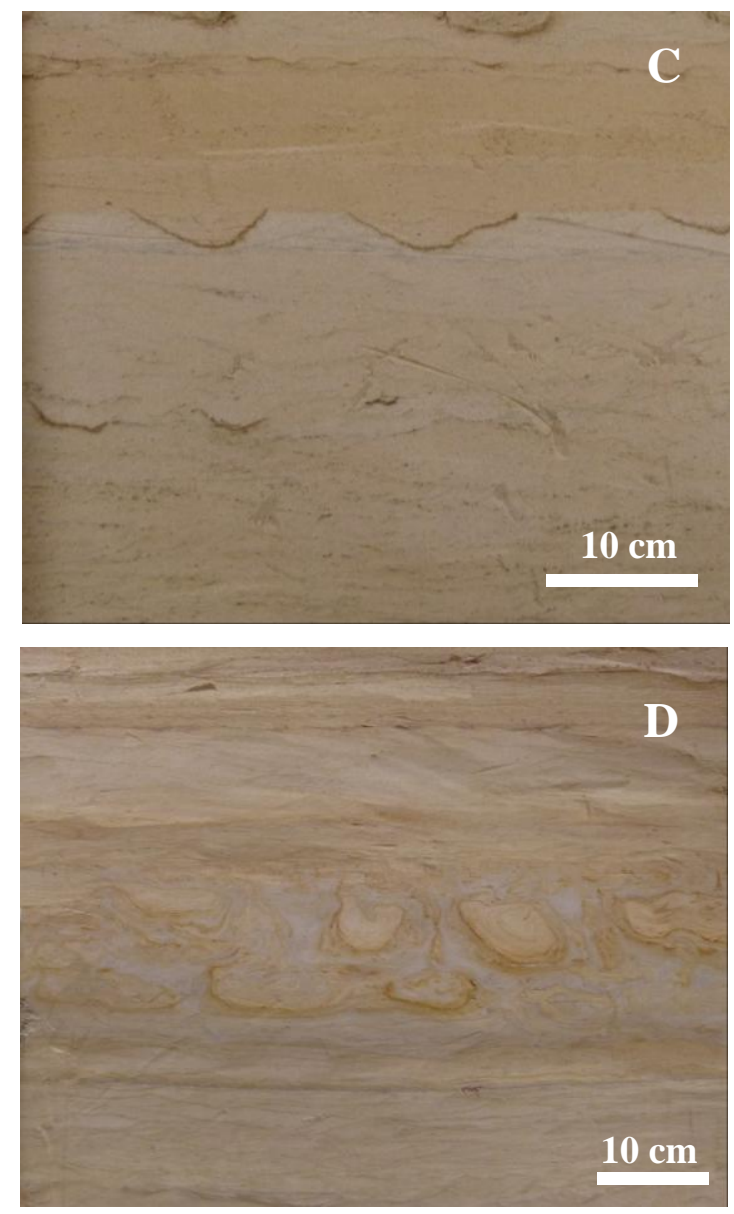

Fig. 4.4. A. Sedimentary log of the Steep Banks outcrop on Terrace III along the right bank of the River Gauja. Legend: Sm - massive sand; Sh - horizontally bedded sand; St - trough cross-bedded sand; Ss - scour-fill sand; Src - climbing-ripple cross-laminated sand; $\mathrm{Sr}$ - ripple cross-laminated sand; SFh - horizontally bedded silty sand; SFrc - ripple cross-laminated sand - ripple cross-laminated silt; FSm - massive sandy silt; FSw - wavy sandy silt; FSm - massive sandy silt; FSd - deformed sandy silt; Fm - massive silt; Fh - parallel laminated silt; FV - silt and clay in varves; Frc - climbing-ripple cross-laminated silt; Fw - wavy laminated silt; I, II, III, IV, V, VI - facies associations; B. lithofacies combined in sedimentation rhythms (numbers show sequence of rhythm); C. truncated upper part of rhythm; D. water escape structures in sandy silt. 
The first facies association (Fig 4.4) was distinguished at $4 \mathrm{~m}$ to $6.18 \mathrm{~m}$ above the present lower mean river water level. It consists of 15 sedimentary rhythms which vary from other facies in having a finer granulometric composition, as well as four layers with wellmarked dehydration structures. The next facies association, which is distinguished at $6.18 \mathrm{~m}$ to $6.95 \mathrm{~m}$ above the present river level, contains four fine sand rhythms. In comparison to the previous one, better expressed in this facies association is horizontally bedded sand, in addition to which planar cross-bedded sand also present.

The third facies association can be distinguished between $6.95 \mathrm{~m}$ and $8.69 \mathrm{~m}$ above the lower mean River Gauja level. It is consists of 7 rhythms. These are characterised by a smooth transition from the unformed ripples to clearly expressed current ripples. The horizontal layers formed in the upper flow regime occur only in some rhythms. In addition, a lamina of silty clay a few millimetres thick which concludes the rhythm has been partially washed away. The next facies association can be distinguished between $8.69 \mathrm{~m}$ and $11.4 \mathrm{~m}$ above the present lower mean river level. It consists of 19 sedimentary rhythms. The lower part of this section consists of clearly expressed sedimentation rhythms with horizontal bedded sand, current ripples and a final silty clay layer. The sinusoidal ripples disappear at the base of this facies. The fifth facies association, encountered at a height of $11.4 \mathrm{~m}$ to $11.87 \mathrm{~m}$ above the lower mean water level, consists of an alternation of 1-2 $\mathrm{cm}$ thick silt lamina with a small admixture of silty sand and $0.5-1 \mathrm{~cm}$ thick darker silty clay lamina.

Another facies association (Fig 4.4) can be identified between $11.87 \mathrm{~m}$ and $12.63 \mathrm{~m}$ above the present lower mean river level, distinguished by brownish grey clay with a silt admixture. In this layer darker horizontal laminae a few millimetres thick are visible. The section ends with a $0.7 \mathrm{~m}$ thick layer of massive fine sand with an admixture of silt.

The basic structure of the sequence indicates seasonally fluctuating water flow regimes and a transgressive sedimentation system which probably indicates base level rise. This is evidenced by nearly homogeneous sediment size composition, texture and well resolved sedimentary cycles, the above-described structural characteristics indicating seasonal changes in the strength of the water flow.

\section{References}

Ābolkalns, J., Majore, M., Stelle, V. 1960. Driasa floras atliekas Gaujas ielejas trešās virspalu terases nogulumos. Proceedings of the Academy of the Latvian SSR, 8(157), 99-107.

Āboltiňš, O. 1969. The types of alluvium of the Holocene terraces of the Gauja river valley. In: Danilāns, I. (ed.), Questions of Quaternary geology, IV. Publishing House „Zinatne”, Rīga, pp. 121-140 (In Russian, with English summary.).

Āboltiņš, O. 1971. Razvitije dolini reki Gauya [Development of the River Gauja valley]. Zinātne, Rīga, 105 pp. (In Russian)

Grīnbergs, E. 1957. Pozdnelednikovaja i poslelednikovaja istorija poberezja Latvijskoj SSR [Late-glacial and postglacial history of the coastal plains of Latvian SSR]. Publishing House of Academy of Sciences of Latvian SSR, Rīga, 122 pp. (In Russian)

Stelle, V., Savvaitov, A.S., Veksler, V.S. 1975a. Datirovaniye pleistotsenovykh otlozheniy na territorii Latvii [Dating of Pleistocene deposits in the territory of Latvia]. In: Savvaitov, A.S., Veksler, V.S. (eds), Opyt $i$ metodika izotopno-geokhimicheskikh issledovaniy v Pribaltike i Belorussii. VNIIMORGEO, Riga, pp. 8081 (in Russian).

Stelle, V., Veksler, V.S., Āboltiņš O. 1975b. Radiouglerodnoye datirovaniye allyuvialnykh otlozheniy srednego techeniya reki Gauyi [Radiocarbon dating of the alluvial deposits of the Middle course of the River Gauya]. In: Savvaitov, A.S., Veksler, V.S. (eds), Opyt i metodika izotopno-geokhimicheskikh issledovaniy v Pribaltike i Belorussi. VNIIMORGEO, Riga, p. 87-88 (in Russian). 

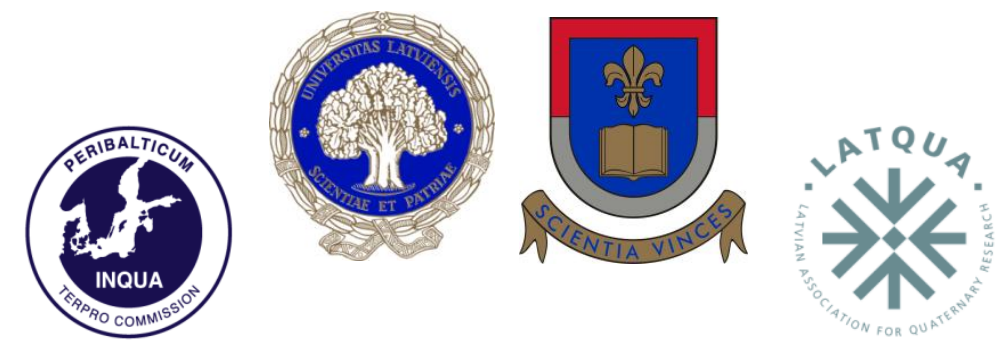

INQUA TERPRO COMMISSION PERIBALTIC WORKING GROUP

UNIVERSITY OF LATVIA

UNIVERSITY OF DAUGAVPILS

LATVIAN ASSOCIATION FOR QUATERNARY RESEARCH

\section{LATE QUATERNARY \\ TERRESTRIAL PROCESSES, SEDIMENTS AND HISTORY: FROM GLACIAL TO POSTGLACIAL ENVIRONMENTS}

EASTERN AND CENTRAL LATVIA

AUGUST 17-22, 2014 


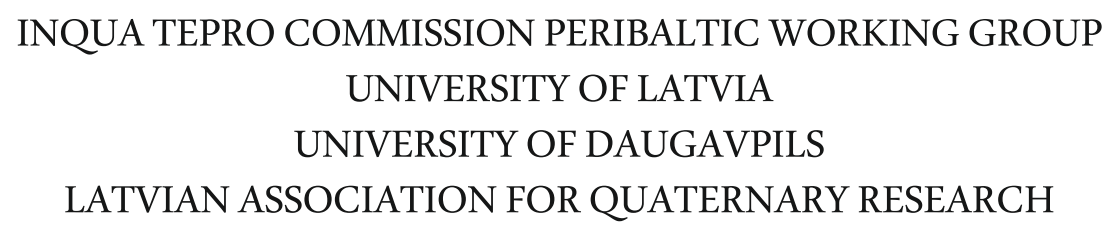

\title{
LATE QUATERNARY \\ TERRESTRIAL PROCESSES, SEDIMENTS AND HISTORY: FROM GLACIAL TO POSTGLACIAL ENVIRONMENTS
}

\author{
EASTERN AND CENTRAL LATVIA
}

AUGUST 16-22, 2014 
Organized by:

University of Latvia

Daugavpils University

Latvian Association for Quaternary Research

INQUA Peribaltic Working Group (INQUA TERPRO Commission)

Organizing committee:

Māris Nartišs (Chair, University of Latvia)

Māris Krievāns (Secretary, University of Latvia)

Aivars Markots (University of Latvia)

Juris Soms (Daugavpils University)

Evija Tērauda (University of Latvia)

Vitālijs Zelčs (University of Latvia)

Contributors:

Ivars Celiņš, Edgars Greiškalns, Ieva Grudzinska, Edyta Kalińska-Nartiša, Laimdota Kalniņa, Jānis Karušs, Māris Krievāns, Kristaps Lamsters, Aivars Markots, Māris Nartišs, Agnis Rečs, Normunds Stivriņš, Juris Soms, Ivars Strautnieks, Santa Strode, Sandra Zeimule, Vitālijs Zelčs

Editors: Vitālijs Zelčs and Māris Nartišs

The English texts of the field guide were revised by Valdis Bērziņš

Recommended reference for this publication:

Zelčs, V. and Nartišs, M. (eds.) 2014. Late Quaternary terrestrial processes, sediments and history: from glacial to postglacial environments. Excursion guide and abstracts of the INQUA Peribaltic Working Group Meeting and field excursion in Eastern and Central Latvia, August 17-22, 2014. University of Latvia, Rīga, 2014, 150 pages.

Sponsored by:

University of Latvia

Layout: Vitālijs Zelčs, Māris Nartišs and Māris Krievāns

ISBN 078-9934-517-60-0

(C) University of Latvia, 2014

This volume is available from:

Faculty of Geography and Earth Sciences

University of Latvia

Rainis Blvd. 19

Rìga, LV1586

Latvia 